\title{
Carbon Value Analysis of Batang Gadis National Park, Mandailing Natal Regency, North Sumatera Province, Indonesia
}

\author{
Dini Novalanty Ohara Daulay, ${ }^{1}$ and Jafron Wasiq Hidayat ${ }^{2}$ \\ ${ }^{1}$ Master Program of Environmental Science, School of Postgraduate Studies, Diponegoro Univers ity, Semarang-Indonesia \\ ${ }^{2}$ Department of Biology, Faculty of Science and Mathematics, Diponegoro University, Semarang-Indonesia
}

\begin{abstract}
Global warming is an important issue in the world which it gives a negative effect on human life. One indicator of global warming is increasing greenhouse gas i.e. carbondioxide from human activities. Deforestation and forest degradation are the second largest contributor of carbon into the atmosphere, after the use of fossil fuels by industry and transportation. As lungs of the world, forest is enable to produce renewable energy sources i.e. biomass. Forest carbon stock in above ground biomass (AGB) is the greatest effect source on deforestation and forest degradation. Therefore, it is necessary to perform a study the potential of carbon in forest. The purpose of this research is to determine carbon stock value in Batang Gadis National Park, Mandailing Natal Regency, North Sumatera Province, Indonesia. The carbon potential stored in this forest vegetation is calculated using AGB allometric equation by using data in diameter at breast height $(\mathrm{dbh}=1.3$ m), height, and density of the wood for trees. Data obtained from secondary data is Asset Assessment Report which State Controlled Forest Natural Resources Batang Gadis National Park, 2016. Study locations were Pagar Gunung and Sopo Tinjak Villages. Carbon stock values were calculated and analyzed with assumption that a half of biomass part is carbon stock which using Australian carbon price about AUD \$11.82 Australia (Australian dollars) and EU $€ 5$ (US \$ 6). The results showed that the total biomass in Pagar Gunung and Sopo Tinjak Villages amounted to 259.83 tonnes and 160.89 tonnes. From the results of the total biomass, the total carbon stocks $(\mathrm{C})$ and $\mathrm{CO}_{2}$ stocks in both villages are 210.36 tonnes (129.92 tonnes in Pagar Gunung Village and 80.45 tonnes in Sopo Tinjak Village) and 772.03 tonnes (476.79 tonnes in Pagar Gunung Village and 295.24 tonnes in Sopo Tinjak Village). By using the carbon price prevailing in the market place Australia Emission Trading System (ETS) and the EU ETS (AUD \$ 11.82/t $\mathrm{CO}_{2} \mathrm{e}$ and $€ 5$ (US \$ 6)/t $\mathrm{CO}_{2} \mathrm{e}$ ), the value of carbon stock that can be produced from Batang Gadis National Park (Pagar Gunung and Sopo Tinjak Villages) is about Rp. 92,499,921.72 (in AUD \$) or Rp. 61,654,433.67 (in US \$).
\end{abstract}

\section{Introduction}

Forest has an important role in maintaining the survival of human life as well as other living creatures. Based on function, forest has three functions, namely conservation, protection, and the production functions [1]. As lungs of the world, forest produces oxygen necessary for human and the ability of absorbing carbon. Forest vegetation that has chlorophyll that capable of absorbing $\mathrm{CO}_{2}$ from the atmosphere through photosynthesis. The results of this photosynthesis is stored as biomass that makes vegetation grow bigger or higher. This growth will continue until the vegetation is physiologically stopped growing or harvested [2].
Forest can reduce excessive carbon emissions in the atmosphere and store it in a variety of separate parts such as vegetation, litter and soil organic matter. Measurement the amount of carbon stored in the body plant life or biomass in an area can describe the amount of carbon dioxide in the atmosphere. Plants or long-lived tree that grows in the forest or in the garden is a mixture of carbon storage dumps or much larger than annual crops. Like-wise woody vegetation is the highest carbon sink [3].

Indonesia is one country that has the largest forest in the world. According to the Ministry of Environment and Forestry data [4], forest area in Indonesia is 124 million hectares nowadays. However, the rate of deforestation is very high every year reached 684.000 hectares. This condition places Indonesia as the second

\footnotetext{
* Corresponding author: dinidaulay29@gmail.com
} 
highest country to lose its forests after Brazil. Forest damage can threaten the extinction of animals and plants in it, so it has an impact on biodiversity degradation. In addition, forest degradation and deforestation also cause an increase in greenhouse gases resulting from $\mathrm{CO}_{2}$ into the atmosphere, causing global warming.

Batang Gadis National Park (BGNP) as a nature conservation area in Indonesia has considerable benefits, tangible and intangible, one of which is the storage and/or sequestration. BGNP comprising several mountainous landscape of the save function as water catchment areas and water sources for some watersheds. This area has a high diversity of flora and fauna are rare flora and fauna (protected). It also has interesting natural beauty, with the cool air, and there are various tourisms potential that can be developed for nature tourism. Unfortunately, this area is also facing of the activities of encroachment caused by forest conversion. These conditions should be solved immediately. Therefore, the calculation of above ground biomass and carbon stock should be undertaken as a first step in simulation the emission modeling and absorption of greenhouse gases in an area. Data or information regarding the carbon value is important as a consideration in the conversion. With the availability of accurate data on carbon stock in some forest types and how much carbon emissions released when forests are converted, is expected to help the government in taking appropriate policy related efforts to reduce carbon emissions from forest deforestation and degradation.

\section{Method}

Batang Gadis National Park (BGNP) is located in Mandailing Natal (Madina) Regency, North Sumatra Province, precisely in Bukit Barisan Mountains of Northern Sumatra. Geographically, BGNP is located at $99^{\circ} 12$ '45 "up to $99^{\circ} 47^{\prime} 10^{\prime \prime}$ east longitude and $0^{\circ} 27$ '15 "up to $1{ }^{\circ} 01^{\prime}$ '57" north latitude. Administratively, this area is in Mandailing Natal (Madina) Regency, North Sumatra Province which includes thirteen districts and sixty-eight villages, where one village of them, the Batahan Village is an enclave in BGNP. The name of this national park is named the main river that flows and splits the Madina Regency i.e. Batang Gadis River. Location BGNP is $\pm 519.1 \mathrm{~km}$ from the capital of North Sumatra Province, Medan.

This area is a stretch of tropical rain forest in the plain topography, the hills to the mountains with an elevation between 300-2145 meters above sea level (top of Sorik Marapi Mountain). Based on the distribution of vegetation, BGNP area are divided into two sub-types of forest formations. First, sub-type Air Bangis-Singkil formation which is part of the Bukit Barisan Westerntype formations hills of medium elevation (300-1000 m asl). Second, sub-type of the Forest of Montana (1000$1800 \mathrm{~m}$ asl), which is part of the Bukit Barisan type formations above 1000 meters above sea level [5].

The secondary data was obtained from the survey i.e. tree list data complete with diameter that comes from Asset Assessment Report which State Controlled Forest Natural Resources Batang Gadis National Park, 2016. In the secondary data, the locations were used as place of research are Pagar Gunung and Sopo Tinjak Villages. Widely used research areas are 0.6 hectares (Pagar Gunung Village) and 0.76 hectares (Sopo Tinjak Village). Estimation of above ground biomass tree is calculated by allometric approach that is based on dbh (diameter breast height /dbh) $1.3 \mathrm{~m}$ above ground level. Allometric equations to estimate the biomass of vegetation, namely:

$$
W=0.11 * \rho^{*} D^{2+c}
$$

Where, $\mathrm{W}=$ biomass per tree $(\mathrm{kg})$,

$\mathrm{D}=\mathrm{DBH}(\mathrm{cm})$,

$\mathrm{P}=$ density of the wood or the density of the wood $\left(\mathrm{g} / \mathrm{cm}^{3}\right.$ or $\left.\mathrm{t} / \mathrm{m}^{3}\right)$,

$\mathrm{c}=$ coefficient that describes the relationship between the diameter and tall tree (used c $=0.62[6]$.

The carbon content is assumed to use the value of the biomass allometric equation where $50 \%$ of the biomass of a forest vegetation is composed of the elements carbon [7]. To convert carbon (C) into $\mathrm{CO}_{2}$, then eq. 2 is used [8]:

$$
\mathrm{CO}_{2}=\mathrm{C}^{*} 3.67
$$

The assessment poles and trees are used to determine the value of carbon in BGNP area. The determination of the carbon is using a carbon price basis ranged Australia AUD \$ 11.82 (Australian dollars) [9] and the EU $€ 5$ (US \$ 6) [10].

\section{Results and Discussion}

Based on the results obtained from secondary data, it can be seen that the species found 418 individual of trees in Pagar Gunung Village and 391 individual of trees in Sopo Tinjak Village. The distribution of tree species is presented in Table 1.

Table 1. The distribution of tree species in Pagar Gunung and Sopo Tinjak Villages

\begin{tabular}{llcccc}
\hline \multirow{2}{*}{ No. } & \multicolumn{1}{c}{ Species } & \multicolumn{2}{c}{ Pagar Gunung Village } & \multicolumn{2}{c}{ Sopo Tinjak Village } \\
\cline { 3 - 6 } & & $\begin{array}{c}\text { Total plot } \\
\text { attendance }\end{array}$ & $\begin{array}{c}\text { Total individual } \\
\text { trees }\end{array}$ & $\begin{array}{c}\text { Total plot } \\
\text { attendance }\end{array}$ & $\begin{array}{c}\text { Total individual } \\
\text { trees }\end{array}$ \\
\hline 1 & Anona spec (tree) & 0 & 0 & 1 & 1 \\
& Anona spec (pole) & 0 & 0 & 1 & 2 \\
2 & Aquilaria mallaccenis (tree) & 2 & 2 & 1 & 1 \\
& Aquilaria mallaccenis (pole) & 1 & 2 & 0 & 0 \\
\hline
\end{tabular}




\begin{tabular}{|c|c|c|c|c|c|}
\hline \multirow[b]{2}{*}{ No. } & \multirow[b]{2}{*}{ Species } & \multicolumn{2}{|c|}{ Pagar Gunung Village } & \multicolumn{2}{|c|}{$\begin{array}{l}\text { Sopo Tinjak Village } \\
\end{array}$} \\
\hline & & $\begin{array}{l}\text { Total plot } \\
\text { attendance }\end{array}$ & $\begin{array}{c}\text { Total individual } \\
\text { trees }\end{array}$ & $\begin{array}{l}\text { Total plot } \\
\text { attendance }\end{array}$ & $\begin{array}{c}\text { Total individual } \\
\text { trees }\end{array}$ \\
\hline \multirow[t]{2}{*}{4} & Cassia fistula (tree) & 3 & 6 & 0 & 0 \\
\hline & Cassia fistula (pole) & 2 & 4 & 0 & 0 \\
\hline \multirow[t]{2}{*}{5} & Cinnamomum subavenum (tree) & 2 & 4 & 0 & 0 \\
\hline & Cinnamomum subavenum (pole) & 1 & 1 & 0 & 0 \\
\hline \multirow[t]{2}{*}{6} & Cratoxylon arborescens (Tree) & 0 & 0 & 3 & 3 \\
\hline & Cratoxylon arborescens (pole) & 0 & 0 & 3 & 16 \\
\hline \multirow[t]{2}{*}{7} & Cryptocarya tomentosa (tree) & 0 & 0 & 2 & 8 \\
\hline & Cryptocarya tomentosa (pole) & 0 & 0 & 1 & 1 \\
\hline \multirow[t]{2}{*}{8} & Dipterocarpus gracilis (tree) & 1 & 5 & 4 & 10 \\
\hline & Dipterocarpus gracilis (pole) & 1 & 1 & 2 & 3 \\
\hline \multirow[t]{2}{*}{9} & Dipterocarpus kunstleri (tree) & 4 & 9 & 2 & 6 \\
\hline & Dipterocarpus kunstleri (pole) & 6 & 10 & 4 & 6 \\
\hline 10 & Ficus benjamina (tree) & 0 & 0 & 1 & 1 \\
\hline \multirow[t]{2}{*}{11} & Ficus drupacea (tree) & 1 & 3 & 1 & 3 \\
\hline & Ficus drupacea (pole) & 1 & 1 & 1 & 1 \\
\hline 12 & Ficus gibbosa (tree) & 1 & 1 & 1 & 1 \\
\hline 13 & Ficus glandulifera (tree) & 1 & 3 & 0 & 0 \\
\hline \multirow[t]{2}{*}{14} & Ficus toxicana (tree) & 4 & 7 & 0 & 0 \\
\hline & Ficus toxicana (pole) & 3 & 3 & 0 & 0 \\
\hline \multirow[t]{2}{*}{15} & Garcinia dioica (tree) & 4 & 6 & 2 & 9 \\
\hline & Garcinia dioica (pole) & 3 & 4 & 2 & 2 \\
\hline 16 & Gluta renghas (tree) & 0 & 0 & 1 & 2 \\
\hline \multirow[t]{2}{*}{17} & Grewia acuminate (tree) & 3 & 21 & 0 & 0 \\
\hline & Grewia acuminate (pole) & 1 & 2 & 0 & 0 \\
\hline 18 & Hopea beccariana (tree) & 1 & 1 & 0 & 0 \\
\hline 19 & Ilex pleiobrachiata (tree) & 0 & 0 & 1 & 1 \\
\hline 20 & Knema conferta (tree) & 3 & 4 & 1 & 2 \\
\hline 21 & Laportea stimulant (tree) & 1 & 1 & 1 & 1 \\
\hline & Laportea stimulant (pole) & 0 & 0 & 2 & 2 \\
\hline 22 & Liex pleiobrachiata (tree) & 6 & 11 & 0 & 0 \\
\hline 23 & Litsea brachystachys (tree) & 11 & 31 & 5 & 8 \\
\hline & Litsea brachystachys (pole) & 5 & 6 & 7 & 10 \\
\hline 24 & Litsea cubeba (tree) & 0 & 0 & 1 & 2 \\
\hline 25 & Litsea firma (tree) & 0 & 0 & 2 & 2 \\
\hline 26 & Litsea odorifera (tree) & 2 & 2 & 0 & 0 \\
\hline & Litsea odorifera (pole) & 1 & 1 & 2 & 2 \\
\hline 27 & Litsea resinosa (tree) & 5 & 24 & 4 & 48 \\
\hline & Litsea resinosa (pole) & 1 & 3 & 2 & 4 \\
\hline 28 & Litsea sp. (tree) & 0 & 0 & 5 & 5 \\
\hline & Litsea sp. (pole) & 0 & 0 & 3 & 3 \\
\hline 29 & Macaranga lowii (tree) & 1 & 15 & 2 & 16 \\
\hline & Macaranga lowii (pole) & 1 & 1 & 1 & 1 \\
\hline 30 & Myristica lowiana (tree) & 1 & 1 & 1 & 1 \\
\hline 31 & Myrtales ningra (tree) & 3 & 3 & 1 & 1 \\
\hline & Myrtales ningra (pole) & 0 & 0 & 1 & 1 \\
\hline 32 & Muraya paniculata (tree) & 1 & 1 & 0 & 0 \\
\hline 33 & Neesia sp. (tree) & 7 & 19 & 0 & 0 \\
\hline 34 & Neonauclea calycina (pole) & 1 & 1 & 0 & 0 \\
\hline 35 & Palagium gutta (tree) & 2 & 2 & 0 & 0 \\
\hline 36 & Palaquim obovatum (tree) & 1 & 1 & 0 & 0 \\
\hline 37 & Palaquim rostratum (tree) & 1 & 1 & 0 & 0 \\
\hline 38 & Palaquim spp. (tree) & 2 & 2 & 7 & 9 \\
\hline & Palaquim spp. (pole) & 0 & 0 & 2 & 2 \\
\hline 39 & Palaquim sumatranum (tree) & 4 & 7 & 0 & 0 \\
\hline 40 & Parkia speciosa (tree) & 1 & 1 & 2 & 2 \\
\hline & Parkia speciosa (pole) & 1 & 1 & 1 & 1 \\
\hline 41 & Phyllanthus indicus (tree) & 1 & 1 & 0 & 0 \\
\hline & Phyllanthus indicus (pole) & 1 & 1 & 0 & 0 \\
\hline 42 & Podocarpus imbricatus (tree) & 0 & 0 & 1 & 1 \\
\hline & Podocarpus imbricatus (pole) & 0 & 0 & 1 & 1 \\
\hline 43 & Podocarpus menifolius (tree) & 2 & 2 & 0 & 0 \\
\hline 44 & Pternandra cordara (tree) & 0 & 0 & 1 & 1 \\
\hline 45 & Quercus gemelliflora (tree) & 3 & 17 & 15 & 32 \\
\hline
\end{tabular}




\begin{tabular}{|c|c|c|c|c|c|}
\hline \multirow[b]{2}{*}{ No. } & \multirow[b]{2}{*}{ Species } & \multicolumn{2}{|c|}{ Pagar Gunung Village } & \multicolumn{2}{|c|}{$\begin{array}{c}\text { Sopo Tinjak Village } \\
\end{array}$} \\
\hline & & $\begin{array}{l}\text { Total plot } \\
\text { attendance }\end{array}$ & $\begin{array}{c}\text { Total individual } \\
\text { trees }\end{array}$ & $\begin{array}{l}\text { Total plot } \\
\text { attendance }\end{array}$ & $\begin{array}{c}\text { Total individual } \\
\text { trees }\end{array}$ \\
\hline & Quercus gemelliflora (pole) & 1 & 2 & 6 & 8 \\
\hline 46 & Shorea hopeifolia (tree) & 0 & 0 & 1 & 1 \\
\hline 47 & Shorea iliginosa (tree) & 1 & 2 & 0 & 0 \\
\hline \multirow[t]{2}{*}{48} & Shorea maxwelliana (tree) & 0 & 0 & 3 & 6 \\
\hline & Dipterocarpus gracilis (pole) & 1 & 1 & 2 & 3 \\
\hline \multirow[t]{2}{*}{49} & Styrax paralleloneurus (tree) & 5 & 6 & 2 & 2 \\
\hline & Styrax paralleloneurus (pole) & 0 & 0 & 1 & 1 \\
\hline \multirow[t]{2}{*}{50} & Syzygium sp. (tree) & 15 & 131 & 12 & 105 \\
\hline & Syzygium sp. (pole) & 7 & 13 & 8 & 14 \\
\hline \multirow[t]{2}{*}{51} & Tabernaemontana macrocarpa (tree) & 0 & 0 & 1 & 1 \\
\hline & Tabernaemontana macrocarpa (pole) & 0 & 0 & 1 & 1 \\
\hline 52 & Urandra scorpiodes (tree) & 2 & 2 & 0 & 0 \\
\hline 53 & Vitaca micrantha (tree) & 0 & 0 & 1 & 1 \\
\hline 54 & Zanthoxylum limonelia (tree) & 1 & 1 & 0 & 0 \\
\hline \multirow[t]{2}{*}{55} & Other species & 0 & 3 & 0 & 15 \\
\hline & Total & & 418 & & 391 \\
\hline
\end{tabular}

Table 1 indicates different species of trees found in both locations. The majority of species of tree in the Pagar Gunung and Sopo Tinjak Villages is Syzygium sp. (Fam: Myrtaceace), with a number of individuals as much as 144 trees in Pagar Gunung Village, and 119 trees in Sopo Tinjak Village. Then, Litsea brachystachys (36 trees), Litsea resinosa (27 trees) in Pagar Gunung Village and Litsea resinosa (52 trees), Quercus gemelliflora (40 trees) in Sopo Tinjak Village. The composition of species diversity in these two locations is very diverse. There are 39 species composition in Pagar Gunung Village and 35 species in Sopo Tinjak Village. From the forest inventories conducted at both locations, approximately 18 trees ( 3 trees on Pagar Gunung Village and 15 trees in Sopo Tinjak Village) recorded are unknown species. The unknown species consists of 3 species in Pagar Gunung Village and 6 species in Sopo Tinjak Village. Distribution of the unknown species in Pagar Gunung and Sopo Tinjak Villages occupy 3 plots and 8 plots both levels of the tree or pole. They are classified as other species and totally of them is very few, only about $2.22 \%$ of the population.

Among the variety of species in both locations, there is one dominant plant species, with the number of plots the presence of 15 (tree) and 7 (pole) from 16 plots observed were Syzygium $s p$. in Pagar Gunung Village by $31.34 \%$ relative density (tree) and $3.11 \%$ (pole), the relative dominance of $15.05 \%$ (tree) and $0.69 \%$ (pole), and Important Value Index (IVI) for $56.46 \%$ (tree) and $8.50 \%$ (pole). In the Sopo Tinjak Village, which has a relative abundance of species and the highest IVI is Syzygium $s p$. with a value of $26.85 \%$ relative density (tree) and $3.58 \%$ (pole), as well as the value of IVI of $53.82 \%$ (tree) and $10.05 \%$ (pole). As for the relative frequency and relative dominance, species that have the highest ratings are Quercus gemelliflora, the relative frequency of $10.56 \%$ (tree) and $4.23 \%$ (pole), and the relative dominance of $18.93 \%$ (tree) and $0.60 \%$ (pole). This is probably because Quercus gemelliflora most commonly found in plots measured. Total plot the presence of this species as many as 15 (trees) and 6 (poles) of the total of 19 plots were observed. In addition, total basal area Quercus gemelliflora is higher than the species Syzygium sp. namely 3.35 and 0.11 . The dominance of these species due to the kind found in large amounts (high density) and is spread almost evenly throughout the area. The types of dominant indicate that these species are more adaptive to environmental conditions, in other words, these species are able to adapt to the environment in its life. In the forest, as a result of competition, certain types of more powerful (dominant) than other types.

\section{1. Distribution of tree diameter class}

Distribution of tree diameter class are shown in Table 2. Approximately $88.04 \%$ and $92.07 \%$ of the trees in Pagar Gunung and Sopo Tinjak Villages are under $40 \mathrm{~cm}$ in diameter, belongs to the class with a diameter $\geq 5-10 \mathrm{~cm}$ followed by a tree in diameter class $>40 \mathrm{~cm}$ (Pagar Gunung Village), 10.1 to $15 \mathrm{~cm}$ (Sopo Tinjak Village). In Pagar Gunung Village, the lowest diameter class (5$10 \mathrm{~cm}$ ) is dominated by tree species Syzygium $s p$. While the class with the highest diameter $(>40 \mathrm{~cm})$ is dominated by tree species Neesia sp.

Table 2. Distribution of tree diameter class

\begin{tabular}{|c|c|c|c|}
\hline \multirow[t]{4}{*}{ No. } & \multirow{4}{*}{$\begin{array}{l}\text { Tree diameter class } \\
\qquad(\mathrm{cm})\end{array}$} & \multicolumn{2}{|c|}{ Total individual trees } \\
\hline & & Pagar & Sopo \\
\hline & & Gunung & Tinjak \\
\hline & & Village & Village \\
\hline 1 . & $\geq 5-10$ & 176 & 194 \\
\hline 2. & $10,1-15$ & 28 & 38 \\
\hline 3. & $15,1-20$ & 42 & 31 \\
\hline 4. & $20,1-25$ & 34 & 30 \\
\hline 5. & $25,1-30$ & 32 & 29 \\
\hline 6. & $30,1-35$ & 33 & 25 \\
\hline 7. & $35,1-40$ & 23 & 13 \\
\hline 8. & $>40$ & 50 & 31 \\
\hline & Total & 418 & 391 \\
\hline
\end{tabular}

Meanwhile, in Sopo Tinjak Village, the lowest diameter class $(\geq 5-10 \mathrm{~cm})$ is dominated by tree species 
Syzygium $s p$. While the highest diameter class $(>40 \mathrm{~cm})$ is dominated by tree species Syzygium $s p$.

The composition of the BGNP forest area in Pagar Gunung and Sopo Tinjak Villages is overgrown vegetation with a variety size of tree diameter. However, in this area is dominated by vegetation with a small diameter. These conditions ensure the survival of the stand to reach the levels of the tree. The larger the diameter of a vegetation, then the numbers will decline. Similar results were shown by research Onrizal, et al. [11] at different locations namely that the tree population in Batang Toru Forest (Aek Game-game forest and Aek Silemes forest) consists of a mixture of a whole class of diameter which is dominated by trees that have a small diameter and density of tree will continue decreases with increasing diameter of the tree so that as the curve "L" which follows a negative exponential function. This is consistent with the model developed by Meyer [12] which described the distribution of diameter (dbh) usually skewed to the right. This classical model showing the condition of the forests are balanced (balanced forest), so that continuity is assured naturally able to stand in the future. However, at this exponential model of individual growth and death of trees are independent to size of the tree, such as disturbance [13].

Diameter of the tree is one of several parameters that affect the biomass in an ecosystem other than the individual density, diversity of tree species, and soil types. Indirectly all the parameters that affect the biomass will also affect carbon stock on a stand. Stem diameter is proportional to the value of biomass. The larger the diameter at breast height (dbh) indicates the old aged trees and old trees store more carbon than the young trees [14].

\section{2. Distribution of tree height class}

Distribution of tree height class on Pagar Gunung and Sopo Tinjak Villages are quite diverse. At level of the tree, the tree density is dominated by height class $<10$ $\mathrm{m}$. Then, continue to decrease until the maximum height class $(>50 \mathrm{~m})$ although at tree height class from 20.1 to $30 \mathrm{~m}$ in Pagar Gunung Village has increased the number of individual tree after falling on the tree height class 10$20 \mathrm{~cm}$. This is as shown in Table 3 .

Table 3. Distribution of tree height class

\begin{tabular}{|c|c|c|c|}
\hline \multirow[t]{2}{*}{ No. } & \multirow{2}{*}{$\begin{array}{l}\text { Tree height } \\
\text { class }(\mathrm{m})\end{array}$} & \multicolumn{2}{|c|}{ Number of individual trees } \\
\hline & & $\begin{array}{c}\text { Pagar Gunung } \\
\text { Village }\end{array}$ & $\begin{array}{c}\text { Sopo Tinjak } \\
\text { Village }\end{array}$ \\
\hline 1. & $<10$ & 188 & 222 \\
\hline 2. & $10-20$ & 89 & 127 \\
\hline 3. & $20,1-30$ & 103 & 41 \\
\hline 4. & $30,1-40$ & 36 & 1 \\
\hline 5. & $40,1-50$ & 1 & 0 \\
\hline 6. & $>50$ & 1 & 0 \\
\hline & Total & 418 & 391 \\
\hline
\end{tabular}

Table 3 shows that the forest area in Pagar Gunung Village composed by a mixture of high-class whole tree. Density of tree height class in low $(<10 \mathrm{~m})$ in Sopo Tinjak Village forest denser than Pagar Gunung Village forest. At Pagar Gunung plot, there is only one tree with a height which included high grade $>50 \mathrm{~m}$, i.e Ficus gibbosa. While, in the Sopo Tinjak Village plot is not found a tree that reaches such a height. The maximum tree height in a Sopo Tinjak Village forest encountered only reached $31 \mathrm{~m}$, which is belong to Syzygium $s p$. (Fam: Myrtaceae). Pagar Gunung and Sopo Tinjak Villages have complete canopy stratum i.e. stratum A, $\mathrm{B}$, and $\mathrm{C}$ although when seen from the existing deployment tree height, Pagar Gunung Village more unevenly distributed than Sopo Tinjak Village. Canopy stratum on Pagar Gunung and Sopo Tinjak Villages generally dominated by the stratum C. This is as stated by Soerianegara and Indrawan [15] that tree with a height of 4-20 meters are categorized in stratum $C$ with continuous canopy characteristics, low tree, and many branches. While the trees with a total height of over 30 meters with a regular layer, diconstinue canopy, tall and straight trunk with a high branch-free trunk categorized as stratum A, and trees with a total height of 20-30 meters with a continuous canopy generally categorized as stratum B. The existence of the canopy layer is very important in supporting the diversity of wildlife, and reducing the kinetic energy of rainwater, which in turn can reduce the risk of erosion.

\section{3. Biomass and Carbon Forest}

Total above ground biomass (AGB) was calculated mainly from trees and poles (i.e, vegetation with height value of more than $1.30 \mathrm{~m}$ ). These classes are defined based on the diameter (dbh) and height (h). Calculation of AGB Pagar Gunung Village forest and Sopo Tinjak Village forest are 405.99 tonnes/ha and 211.70 tonnes/ha. In total the highest average AGB in Pagar Gunung Village for all stands of trees found in the class $>40 \mathrm{~cm}(291.78$ tonnes/ha) and the average of the lowest AGB found at diameter class $\geq 5-10 \mathrm{~cm}$ diameter class with total about 2.33 tonnes/ha. While, in Sopo Tinjak Village found the highest average total AGB for all stands at the trees with diameter class $>40 \mathrm{~cm}$ (139.96 tonnes/ha) and the average of the lowest AGB found in diameter class $\geq 5-10 \mathrm{~cm}$ with a total average 2.36 tonnes/ha. From these results show that more than $94 \%$ of the total AGB consists of a tree. This is as stated in Table 4.

Table 4. Biomass tree with tree diameter class

\begin{tabular}{cccc}
\hline No. & $\begin{array}{c}\text { Tree diameter } \\
\text { class }(\mathrm{cm})\end{array}$ & \multicolumn{2}{c}{ Biomass (tonnes/ha) } \\
\cline { 3 - 4 } & & $\begin{array}{c}\text { Pagar Gunung } \\
\text { Village }\end{array}$ & $\begin{array}{c}\text { Sopo Tinjak } \\
\text { Village }\end{array}$ \\
\hline 1. & $\geq 5-10$ & 2.33 & 2.36 \\
2. & $10,1-15$ & 2.69 & 2.73 \\
3. & $15,1-20$ & 9.16 & 5.67 \\
4. & $20,1-25$ & 14.27 & 9.55
\end{tabular}




\begin{tabular}{cccc}
5. & $25,1-30$ & 20.07 & 15.74 \\
6. & $30,1-35$ & 32.16 & 19.71 \\
7. & $35,1-40$ & 33.54 & 16.00 \\
8. & $>40$ & 291.78 & 139.96 \\
\hline & Total & 405.99 & 211.70 \\
\hline
\end{tabular}

Above ground biomass (AGB) on the Pagar Gunung and Sopo Tinjak Villages are 405.99 tonnes/ha and 211.70 tonnes/ha. When multiplied by the area of each area is 0.64 ha for Pagar Gunung Village and 0.76 ha for Sopo Tinjak Village, the total biomass of both locations are 259.83 tonnes and 160.89 tonnes. In Table 5, it shows that the diameter of the tree is very affected by biomass. The bigger the diameter of the tree, the bigger the biomass. Diameter growth was positively correlated with increasing biomass of trees as well as the amount of carbon stock in vegetation. This condition is consistent with the Windardi's statement [16] which stated that the vegetation is strongly influenced by amount of biomass that is owned. Biomass in every part of the tree increases proportionally with increasing magnitude of the tree diameter so that the tree biomass in each section have a relationship with the tree diameter [17].

Forest biomass is particularly relevant to the issue of climate change. Forest biomass has an important role in biogeochemical cycles, especially in the carbon cycle. Of the total forest carbon, about $50 \%$ of them are stored in forest vegetation [18]. The carbon content can be estimated by using biomass values obtained from allometric equation where biomass is carbon stored. From the previously known biomass value, the total carbon storage (C) in Pagar Gunung and Sopo Tinjak Villages are 129.92 tonnes and 80.45 tonnes (Figure 1). Potential carbon stocks (C) is equivalent to 476.79 tonnes of $\mathrm{CO}_{2}$ for Pagar Gunung Village and 295.24 tonnes of $\mathrm{CO}_{2}$ for Sopo Tinjak Village. These results suggest that carbon stock in both locations are quite high. This is in line with the Windardi's statement [16] which stated that if the value of vegetation biomass is large then the resulting carbon value conversion is also large.

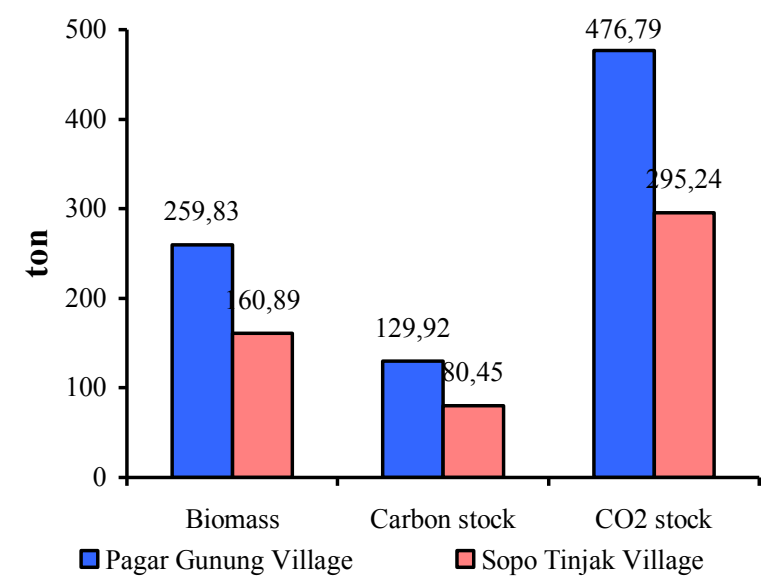

Fig. 1. Biomass, carbon stock, $\mathrm{CO}_{2}$ stock in the BGNP forest (Pagar Gunung and Sopo Tinjak Villages)
Carbon stock in an area affected by type of vegetation. A trunk diameter of vegetation would indirectly also affect carbon storage on a stand [14]. When compared with the results of the two locations of Batang Toru primary forests i.e. Aek Silemes forest and Aek Game-game forest, AGB and carbon stock in forests BGNP (Pagar Gunung and Sopo Tinjak Villages) are lower. At Batang Toru primary forests (Aek Silemes forest and Aek Game-game forest), AGB are ranged from 544.4 to 583.0 tonnes/ha on Aek Silemes forest and 604.5 to 613.6 tonnes/ha on Aek Game-garne forest. While, carbon stocks are 272.2 to 291.5 tonnes $\mathrm{C} /$ ha on Aek Silemes forest and 302.2-306.8 tonnes C/ha on Aek Game-game forest. Location altitudes in Batang Toru primary forests are an altitude of 850-975 $\mathrm{m}$ above sea level (Aek Silemes forest) and 625-800 m above sea level (Aek Game-game forest) [11]. While, location altitudes of BGNP forests (Pagar Gunung and Sopo Tinjak Villages) are an altitude of \pm 1000 to $1150 \mathrm{~m}$ asl \pm 1200 to $1500 \mathrm{~m}$ asl. From these results indicate that the higher a site that would lower carbon stock. Conversely, if the lower one location then carbon stock will be higher. Altitude affects the species composition and diameter class [19.11]. It is also associated with rainfall and temperature. The higher somewhere, then the higher the rainfall intensity and the temperature will be lower. This condition is in line with Onrizal, et al. statement [11]; Zilikifli, et al. [20] which stated that forest biomass is influenced by climatic factors (rainfall and temperature) associated with the rate of increase of forest biomass and climatic differences (differences in the rate of production of organic material).

Carbon emissions trading is now a critical need given the increasing climate of the world up to 5 degrees Celsius. If this condition is allowed, it can bring damage to the environment. To achieve the target of reducing carbon dioxide emissions, then Protoko Kyoto (1997), which discussed the framework of the climate change convention (Framework Convention on Climate Change, FCCC) has agreed that industrialized countries will reduce emission levels averaged $5.2 \%$ below the level 1990 in 2008 to 2012 including emissions trading mechanisms. Carbon trading is a way relieve the burden on the industrialized countries to reduce their emissions. Usually, the trade is done between the developed and developing countries [21].

Determination of the carbon value in the global carbon trading market can be done through several mechanisms i.e. joint implementation (JI) and clean development mechanism (CDM). At joint implementation mechanism, an industrialized country invests emission reduction projects in other industrialized countries. Emission reduction credits gained from the implementation of the project will be given to countries that make investments. At CDM mechanism, industrial and developing countries working together to undertake clean development. Through CDM, industrialized countries can reduce their emissions by undertaking emission reduction projects while developing countries will receive financial and 
technological compensation from such cooperation. Emissions trading may be mandatory (required by government) or voluntary. Nowadays, the countries that have been trading carbon in their exchanges such as The European Union, The United States, Australia, New Zealand, and Japan i.e. European Climate Exchange, NASDAQ OMX European Commodities, PowerNext, Commodity Exchange Bratislava, European Energy Exchange, Carbon Trade Exchange, and Chicago Climate Exchange. Determination of carbon values in this study are using carbon price in the Australian Emission Trading System (ETS) AUD \$ 11.82/t CO2e, and European Union ETS $€ 5$ (US \$ 6)/t CO2e. The amount of carbon dioxide stock (CO2) in Pagar Gunung and Sopo Tinjak Villages is 772.03 tonnes, so the total carbon value is Rp. 92,499,921.72 (in AUD \$) or Rp. $61,654,433.67$ (in US \$). From these results indicate that carbon value in the forest area of BGNP, especially Pagar Gunung and Sopo Tinjak Villages is relatively high. This indicates that forest condition in both locations is still good. Therefore, various conservation efforts need to be done continuously in the forest area in Pagar Gunung and Sopo Tinjak Villages in order to maintain the balance of environment ecosystem.

\section{Conclusion}

Above ground biomass (AGB) found in BGNP forest area i.e. Pagar Gunung and Sopo Tinjak Villages are 405.99 tonnes/ha and 211.70 tonnes/ha. If multiplied by the area of each area of 0.64 ha for Pagar Gunung Village and 0.76 ha for Sopo Tinjak Village, the total biomass of both sites are 259.83 tonnes and 160.89 tonnes. At the highest mean total AGB in Pagar Gunung Village for all stands found in trees with diameter class > $40 \mathrm{~cm}$ (291.78 tonnes/ha) and the lowest average AGB is found in diameter class $\geq 5-10 \mathrm{~cm}$ with average total 2.33 tonnes/ha. While in Sopo Tinjak village found the highest total average AGB for all stands in trees with diameter class $>40 \mathrm{~cm}$ (139.96 tonnes/ha) and the lowest average AGB was found in $\geq 5-10 \mathrm{~cm}$ diameter class with average total 2.36 tonnes/ha. From the total biomass result, the total carbon stock for both locations are 210.36 tonnes (129.92 tonnes in Pagar Gunung Village and 80.45 tonnes in Sopo Tinjak Village) or equivalent with a total of $\mathrm{CO}_{2}$ is 772.03 tonnes (476.79 tonnes in Pagar Gunung Village and 295.24 tonnes in Sopo Tinjak Village). By using the applicable carbon price in the Australian Emission Trading System (ETS) AUD $\$ 11.82 / \mathrm{t} \mathrm{CO} 2$ e, and European Union ETS $€ 5$ (US $\$ 6) / \mathrm{t} \mathrm{CO} e$, the carbon value that can be generated from BGNP forest areas (Pagar Gunung and Sopo Tinjak Villages) is Rp. 92,499,921.72 (in AUD \$) or Rp. $61,654,433.67$ (in US \$). From these results indicate that carbon value in the forest area of BGNP, especially Pagar Gunung and Sopo Tinjak Villages is relatively high. This indicates that forest condition in both locations is still good. Therefore, various conservation efforts need to be done continuously in the forest area in
Pagar Gunung and Sopo Tinjak Villages in order to maintain the balance of environment ecosystem.

\section{References}

1. Undang-Undang Nomor 41, Kehutanan (1999).

2. K. Borje, Unasylva, 41, 4 (1990).

3. H. Kurniatun, R. Subekti., Pengukuran karbon tersimpan di berbagai macam penggunaan lahan (2007).

4. C. Hendra, Setiap tahun, hutan Indonesia hilang 684.000 hektar, http://regional.kompas.com/read/2016/08/30/15362 721/setiap.tahun.hutan.indonesia.hilang.684.000.h ektar (Accesed on July 11, 2017).

5. Balai Konservasi Sumber Daya Alam Sumatera Utara II, Rencana Pengelolaan Taman Nasional Batang Gadis (RP-TNBG) (2005).

6. K. Quirine, R. Coe, M. V. Noordwijk, Y. Ambagau, C. A. Palm, Forest Ecology and Management, 146, 199-209 (2001).

7. B. Sandra, FAO Forestry Paper, 134 (1997).

8. M. V. Martin, Carbon budget accounting at the forest management unit level: an overview of issues and methods (Canada's model forest program, 2000).

9. Australian Government Clean Energy Regulator, Auction April 2017, http://www.cleanenergyregulator.gov.au/ERF/Aucti ons-results/april-2017 (Accesed on July 11, 2017).

10. World bank group climate change, Ecofys, Carbon Pricing Watch (2016).

11. Onrizal, Ismail, E. A. Perbatakusuma, H. Sudjito, J. Supriatna, I. H. Wijayanto, Jurnal Biologi Indonesia, 5, 2, 187-199 (2008).

12. Meyer, H. A, Journal of Forestry. 50, 2, 85-92 (1952).

13. L. De Renato Augusto Ferreira, J. L. F. Batista, P. I. Prado, Forest Science, 61, 2, 320-327 (2015).

14. R. Subekti, B. Lusiana, M. V. Noordwijk, Pendugaan cadangan karbon di atas permukaan tanah pada berbagai sistem penggunaan lahan di Kabupaten Nunukan, Kalimantan Timur, ICRAF (2007).

15. S. Ishemat, A. Indrawan, Ekologi Hutan Indonesia (2005).

16. W. Aditya C, Struktur komunitas hutan mangrove, estimasi karbon tersimpan dan perilaku masyarakat sekitar kawasan Segara Anakan Cilacap, Thesis (2014).

17. A. W. Catur, K. Sidiyasa, Jurnal Penelitian Hutan dan Konservasi Alam, 3, 1, 103-117 (2006).

18. S. Dandun, Penghitungan biomassa sebuah pengantar untuk studi karbon dan perdagangan karbon (2009).

19. K. Wanda, B. S. Antoko, Jurnal Penelitian Hutan dan Konservasi Alam, 5, 4, 337-354 (2008). 
20. Z. Hilda, Y. Windusari, I. Yustian, D. Heriinawati, Prosiding seminar nasional dan rapat tahunan dekan bidang ilmu-ilmu pertanian badan kerja sama perguruan tinggi negeri (BKS-PTN) wilayah barat, 3 (2011).
21. S. Barliana S, Indonesia produsen emisi karbon dunia,

https://www.bappebti.go.id/id/edu/articles/detail/29 97.html (Accesed on July 11, 2017). 